\title{
SPECIFIC FEATURES OF UROGENITAL MICROBIOCENOSIS IN WOMEN WITH UROGENITAL MIXED INFECTIONS
}

DOI: 10.36740/WLek202104103

\author{
Nataliya Yu. Bysaha' ${ }^{1}$ Oxana Ol. Korchynska', Stefania Andrascikova ${ }^{2}$, Silvia Zultakova ${ }^{2}$, Alena Schlosserova ${ }^{2}$ \\ 'DEPARTMENT OF OBSTETRICS AND GYNECOLOGY, MEDICAL FACULTY, UZHHOROD NATIONAL UNIVERSITY, UZHHOROD, UKRAINE \\ 2PRESHOV UNIVERSITY, PRESHOV, SLOVAKIA
}

\begin{abstract}
The aim: Studying the features of urogenital microbiocenosis in women with urogenital mixed infections.

Materials and methods: In an open comparative randomized study, we surveyed 90 women of childbearing age who sought outpatient treatment at a women's health clinic in Uzhhorod.

Results: During studying the urogenital microflora of the above groups, the following pattern was observed: patients of the main group had a violation of the resident to facultative flora ratio (dysbiosis) on the background of borderline changes in the vaginal mucosa, mainly due to hormonal imbalance manifested by pathological vaginal discharge; instead, in the control group patients, the urogenital flora was saturated with a significant number of lactobacilli (90\%).

Conclusions: The women urogenital tract damage by several pathogens simultaneously has been found.
\end{abstract}

KEY WORDS: urogenital infections, microbiota, inflammatory diseases of pelvic organs

Wiad Lek. 2021;74(4):828-831

\section{INTRODUCTION}

The term "urogenital infections" includes diseases characterized by damage to the mucous membranes of the urinary tract and genital tract. The course of these diseases is often complicated by involvement in the inflammatory process of the upper genital and urinary tracts, as well as the rectum. Urogenital infections pose a real threat to reproductive health, as they can cause infertility, complicated pregnancy and miscarriages. According to modern ideas and the results of numerous studies, chronic inflammatory process of the genitals many times increases the risk of HIV infection [1-3].

Risk factors that contribute to the development of this pathology should be early sexual life in adolescents, frequent change of sexual partners, neglect of barrier contraception, alcohol, smoking, drug addiction, vitamin deficiency, malnutrition, stress, decreased immunity $[4,5]$.

All of the above suggests that chronic inflammatory diseases of the female genital organs lead to severe changes in a woman's reproductive system - infertility, menstrual dysfunction, polycystic ovaries, uterine fibroids, endometrial hyperplastic processes, formation of joints in the area of pelvic organs. The anatomical location of the external genitalia and vagina - their close proximity to the anus and urinary tract - provides a high frequency of microorganism exchange between the intestine and urogenital tract, which also contributes to the spread of infection.

\section{THE AIM}

Studying the features of urogenital microbiocenosis in women with urogenital mixed infections.

\section{MATERIALS AND METHODS}

In an open comparative randomized study, we surveyed 90 women of childbearing age who sought outpatient treatment at a women's health clinic in Uzhhorod.

The patients were divided into two representative clinical groups: the main group consisted of 60 patients with complaints of inflammatory urogenital tract lesions; the control group included 30 patients without signs of inflammation of the urinary and genital tracts.

Criteria for inclusion in the study were as follows:

- reproductive age;

- no pregnancy;

- the presence of complaints of discharge from the genital tract;

- irritation, burning in the vagina;

- frequent, painful urination;

- dyspareunia.

Exclusion criteria were as follows: pregnant women, patients with bleeding at the time of treatment due to benign hyperproliferative or malignant processes in the genital and urinary tract, children and postmenopausal age, the presence of cervical dysplasia.

All patients included in the study underwent gynecological examination, bacterioscopy and bacteriological exam- 
ination with antibioticogram of vaginal and urethral secretions, oncocytology, colposcopy, PCR to detect chlamydia, gonococci, trichomonas, genital herpes, antipsychotics, cytomegalovirus, cytomegalovirus in accordance with the regulatory base adopted in Ukraine. Appropriate test systems were used in this research, such as: Euroimmun, Ampli-Sens, Tecan Sunrise (Germany). The premorbid background, the nature of menstrual function, the presence of a history of the pelvic organs inflammatory diseases and extragenital pathology were taken into account. The results obtained were processed by parametric statistics methods using the Excell software package adapted for biomedical research.

This study was carried out in compliance with ethical norms and rules adopted for biomedical research.

\section{RESULTS}

The composition of the urogenital microbiota of a healthy woman may have specific features dependent of the menstrual cycle phase and age $[5,6]$. The optimal number and species composition of lactobacilli provides the acidity of vaginal secretions in the range of 4-4.5, the formation of a barrier for the fixation of opportunistic and pathogenic flora to vaginal epithelial cells, and also participates in a number of immune mechanisms $[5,7]$. The composition of the microbiome is strongly correlated with the vaginal mucosa condition that depends primarily on the levels of sex hormones, including estrogen. The latter fact stimulates the proliferation of multilayered squamous epithelium and the production of glycogen in surface cells, which is a substrate for the lactobacilli activity $[5,8]$. During studying the urogenital microflora of the above groups, the following pattern was observed: patients of the main group had a violation of the resident to facultative flora ratio (dysbiosis) on the background of borderline changes in the vaginal mucosa, mainly due to hormonal imbalance manifested by pathological vaginal discharge; instead, in the control group patients, the urogenital flora was saturated with a significant number of lactobacilli (90\%). It is known that vaginal dysbiosis increases the likelihood of colonization by obligate-pathogenic flora. Recently, the data have been obtained on the possible influence of the dominance of certain species of facultative vaginal flora on the persistence of human papilloma virus and its carcinogenic potential $[9,10]$.

The age of the patients participated in the study was as follows: the main group with the average age of $24 \pm 1.2$ years; the control group with the average age of $23 \pm 1.1$ years. Patients of the main group visited the women's clinic on the $1^{\text {st }}-3^{\text {rd }}$ day of disease (average number being $2.16 \pm$ 0.08 days). From the anamnesis it is known that 32 (53\%) patients of the main group had a burdened gynecological anamnesis and previously sought medical help in view of inflammatory diseases (colpitis, cervicitis, chronic salpingo-oophoritis, cystitis), compared with the control one, where the anamnesis was not burdened. When seeking medical advice, the patients of the main group complained of vaginal discharge - 56 (94\%) women; itching, burning in the genital area - $58(97 \%)$ persons; accelerated urination - 55 (92\%) women; dysuria - 58 (97\%) persons; pain associated with sexual intercourse - $60(100 \%)$ patients. The main group patients, unlike the control group ones, had a following peculiarity: most of them 45 (75\%) women were single with uncontrolled sexual intercourse and a large number of partners; 27 (90\%) patients of the control group were married having one sexual partner; the socio-economic status of women in the main group was lower than that in the control group.

One should note the increased virulence of microorganisms, which are the trigger in the IPOD emergence. The spread of the infectious process can be facilitated by disordered sexual intercourse (with partners whose semen is the source of infection), intrauterine interventions, postpartum purulent-septic complications. The condition of women with this pathology is often influenced by socalled risk factors that not only cause exacerbation of the infectious process, but also are directly involved in the pathogenesis. These include unfavorable environmental situation in the place of residence (up to $12 \%$ ), dangerous influence of certain occupational moments (8\%), and bad habits (30-43\%). It is known that various environmental factors, interpersonal relationships, violations of biological regimes can cause stress $[8,9]$.

When studying the premorbid background in 48 (80\%) patients of the main group, there was a transferred bilateral salpingo-oophoritis with outpatient antibacterial, anti-inflammatory therapy, 17 (28\%) patients with pelvic inflammatory disease suffered from the menstrual cycle violation of the dyspepsia type. In the control group patients, inflammatory pelvic organs (PO) processes, as well as violations of the ovarian-menstrual cycle, were not observed (normal menstrual function was preserved).

Bacterioscopic examination of vaginal discharge provided the following results: leukocytosis was detected in 54 (90\%) patients of the main group, coccal and mixed microflora was observed in $35(59 \%)$ women, specific pathogenic microflora was found in 21 (35\%) persons. It should be noted that the specific pathogenic microflora of the vagina was represented by trichomonas in $4(7 \%)$ patients, chlamydia - in 4 (7\%) women, yeast cells and fungal spores - in 7 (12\%) patients. Bacterioscopy of allocations in the control group patients has shown no specific features and demonstrated vagina normoflora in all cases.

Initial visual and colposcopic examination revealed hyperemia and edema of the vaginal mucosa in $60(100 \%)$ patients of the main group, ectopia of the cylindrical epithelium was visualized in $25(42 \%)$ cases, incomplete transformation zone - in $23(38 \%)$ cases. Only the type II cytological picture in these women was observed for 60 patients $/ 100 \%$, whereas vaginal cleanliness of type III-IV was noticed. In the control group women, colpocytology showed no complaints and normal colposcopic pattern was observed.

Bacteriological examination of cervical canal and vaginal secretions in the examined patients from the main group revealed before treatment a combined nonspecific mixed 
infection of the urogenital habitat against the background of lactobacilli microflora suppression. In all patients, the microbial landscape was represented by the gram-negative and gram-positive bacteria of different colonization degrees, i.e. St. aureus $\geq 105 \mathrm{CFU} / \mathrm{ml}$ - in 38 (63\%) cases, St. epidermidis $\geq 105 \mathrm{CFU} / \mathrm{ml}$ - in $23(38 \%)$ cases, Bacteroides fragilis $\geq 104 \mathrm{CFU} / \mathrm{ml}$ - in 17 (28\%) cases, Peptostreptococcus spp. $\geq 104 \mathrm{CFU} / \mathrm{ml}$ - in 21 (35\%) cases, Escherichia coli $\geq 104 \mathrm{CFU} / \mathrm{ml}$ - in $42(70 \%)$ patients with a decrease in the number of Lactobacillus spp. The yeast-like fungi of the genus Candida spp. $\geq 104 \mathrm{CFU} / \mathrm{ml}$ were detected in 9 $(15 \%)$ cases only. In the control group women, the urogenital microbiota was represented by a normal amount of Lactobacillus spp.

General analysis of urine in all patients of the main group (60 women) has shown leukocyturia (16-20 in field of view), squamous epithelium (10-12 in field of view), cylindruria (6-8 in field of view), mucus and bacteria $(++)$, while the urine in the control group women (30 patients) was normal, with no pathology. Regarding urine culture in the main group, the following clinical pattern was observed: E. coli $\geq 105 \mathrm{CFU} / \mathrm{ml}$ - in 42 (70\%) cases, St aureus $\geq 105$ $\mathrm{CFU} / \mathrm{ml}$ - in 32 (53\%) cases, Klebsiella $\geq 106 \mathrm{CFU} / \mathrm{ml}$ - in 13 (22\%) cases, Enter. faecalis $\geq 107 \mathrm{CFU} / \mathrm{ml}-$ in $10(17 \%)$ women. In all the control group patients, the urine bacterial culture had no pathogenic microflora.

\section{DISCUSSION}

Inflammatory pelvic organs diseases (IPOD) are a hot problem in modern gynecology, as they occupy the first place in its structure (up to $70 \%$ ), and also lead to serious long-term complications. Among them one should note infertility, chronic pelvic pain syndrome, ectopic pregnancy, miscarriage $[9,10]$. The most noteworthy are urogenital infections, which are clinically manifested in the form of colpitis, cervicitis, chronic salpingo-oophoritis, cystitis, asymptomatic bacteriuria, chronic and gestational pyelonephritis, as well as extragenital infection foci that, in turn, cause complications and consequences unless detected or treated in proper time. After all, the biggest problem is the fact that in $80 \%$ of cases urogenital infection is latent and its presence in a woman may not be even suspected [1-3].

The urogenital microflora (microbiota) is a complex dynamic ecosystem. It includes normal/resident flora, which, in turn, is divided into the obligate and facultative ones. Under certain physiological conditions, the urogenital microbiota includes transient flora. Acquired flora can be represented by opportunistic pathogens [5]. The condition and composition of the vaginal microbiota is influenced by a large number of endogenous and exogenous factors that may or may not be modified. It is known that the dominant microorganisms of the vaginal microbiome are different species of lactobacilli (Lactobacillus spp.): Lactobacillus crispatus, Lactobacillus gasseri, Lactobacillus iners, Lactobacillus jensenii. Other species are normally present in much smaller quantities, i.e. Bacteroides, Fusobacterium, Veillonela, Actinomycetes, Bifidobacterium, Peptococcus, Peptostreptococcus, Propionibacterium, Staphylococcus aureus, Staphylococcus epidermidis, Streptococcal varicardia.

When the microbiota of the above ecosystems in the vaginal biotope is disturbed, the concentration of bacteria of the genera Bacteroides, Fusobacterium, Peptostreptococcus, Clostridium, Eubacterium, Veillonella, Escherichia, Enterococcus, Mobiluncus, Gardnerella, Mycoplasma hominischialis increases, causing inflammatory urogenital process $[1,3,7]$.

\section{CONCLUSIONS}

1. A high frequency of simultaneous lesions by the same pathogens of several anatomical areas, i.e. vagina, cervix, urethra, bladder, has been noted.

2. The above peculiarities require application of a multidisciplinary approach involving in treatment urologist and nephrologist.

The immune system of women with chronic urogenital infections in non-pregnancy status corresponds to the presence of an infectious process with changes at the systemic level. Such changes are the signs of an infectious process, they should be considered natural and cannot be considered as factors of infection, but only as its consequences and signs of specific or nonspecific inflammation.

\section{REFERENCES}

1. Radzynskyi V.E. Infektolohyia dvadtsat pervoho veka: neprostie otveti / Infektsyy i infektsyonnii kontrol [Infectious diseases of the XXI century: difficult answers / Infection and infection control]. Status Praesens. 2012; 2 (8):5-7. (In Russian).

2. Albota 0.M., Berbets A. M. Mozhlyvist vykorystannia vahinalnoi tabletky mikronizovanoho prohesteronu pry bakterialnomu vahinozi u vahitnykh [The possibility of using a vaginal tablet of micronized progesterone in bacterial vaginosis in pregnant women]. Zhinochyi likar. 2016; 5 (67):48-50. (In Ukrainian).

3. Pasiechnikov S.P. Tsystyt: etiopatohenez, klasyfikatsiia, klinichna kartyna, diahnostyka, likuvannia [Cystitis: etiopathogenesis, classification, clinical picture, diagnosis, treatment]. Ukrainskyi Medychnyi Chasopys. 2016; 4 (114):34-37. (In Ukrainian).

4. Lakhno Y.V., Hryshchenko O.V. Stupenchataia terapyia vahynalnoho dysbyoza: mozayka dokazatelstv [Stepwise therapy for vaginal dysbiosis: a mosaic of evidence]. Reproduktyvna endokrynolohiia. 2016;2 (28):5859. (In Russian).

5. Yankovskyi D.S., Shyrobokov V.P., Antypkyn Yu.H. et al. Mykrobyom y zdorove zhenshchynd [Microbiome and women's health]. Reproduktyvna endokrynolohiia Almanakh reproduktyvnoho zdorovia. 2015:26-48. (In Russian).

6. Volodyna T.A., Saskova P.V., Yvanova E.V. Urohenytalnbi khlamydyoz: sovremennoe sostoianye voprosa (obzor) [Urogenital chlamydia: current state of the art (review)]. Farmatsyia y farmakolohyia. 2014; 6 (7):66-73. (In Russian).

7. Geerlings, S.E. Clinical Presentations and Epidemiology of Urinary Tract Infections. Microbiol Spectr. 2016; 4. doi: 10.1128/

8. Gupta K., Trautner B.W. Diagnosis and management of recurrent urinary tract infections in non-pregnant women. BMJ. 2013. doi: 10.1136. 
9. Rossignol L., Vaux S., Maugat S. et al. Incidence of urinary tract infections and antibiotic resistance in the outpatient setting: a cross-sectional study (n.d.) Infection 45.1 (2017): 33-40. doi: 10.1007/s15010-0160910-2.

10. Vovk I. B, Horban N. I, KondratiukV. K. et al. Optymizatsiia kompleksnoho likuvannia zapalnykh zakhvoriuvan henitalii u zhinok reproduktyvnoho viku [0ptimization of complex treatment of inflammatory diseases of the genitals in women of reproductive age]. DU Instytut pediatrii, akusherstva i hinekolohii NAMN Ukrainy. Informatsiinyi lyst №8. 2015. (In Ukrainian).

11. Antonenko Y.V. Patohenetycheskye aspektы lechenyia vospalytelnыkh zabolevanyi vnutrennykh zhenskykh polovыkh orhanov na sovremennom эtape [Pathogenetic aspects of the treatment of inflammatory diseases of the internal female genital organs at the present stage]. Reproduktyvnaia endokrynolohyia. 2016; 4 (30):70-72. (In Russian).

12. Kohan B.H. Rol kombynyrovannukh sredstv v kompleksnom lechenyy vospalytelnыkh zabolevanyi zhenskykh polovыkh orhanov smeshannoi atyolohyy [The role of combined agents in the complex treatment of inflammatory diseases of female genital organs of mixed etiology]. Zdorove zhenshchynы. 2014; 5 (91):86-90. (In Russian).

13. Maiorov M.V. Vospalytelnыe zabolevanyia orhanov maloho taza: rol kombynyrovannoi terapyy [Pelvic inflammatory disease: the role of combination therapy]. Medytsynskye aspektы zdorovia zhenshchynы. 2017; 2 (107):58-64. (In Russian).

\section{ORCID and contributionship:}

Nataliya Y. Bysaha: 0000-0001-6226-7294 ${ }^{A, B}$

Oxana O. Korchynska: 0000-0001-7265-4829 C,D

Stefania Andrascikova: 0000-0001-7960-6168 ${ }^{\mathrm{E}}$

Silvia Zultakova: 0000-0003-0964-5748 ${ }^{\mathrm{F}}$

Alena Schlosserova: 0000-0002-1747-1429 C,E

\section{Conflict of interest:}

The Authors declare no conflict of interest.

\section{CORRESPONDING AUTHOR Nataliya Y. Bysaha \\ Uzhgorod National University \\ 1Sq. Narodna, 88000 Uzhhorod, Ukraine \\ tel: +380506715683 \\ e-mail:your_natali@yahoo.com}

Received: 17.10 .2020

Accepted: 05.03.2021

A - Work concept and design, B - Data collection and analysis, C - Responsibility for statistical analysis, D -Writing the article, $\mathbf{E}$-Critical review, $\mathbf{F}$ - Final approval of the article 